\subsection{Minataur: the Mintek Alternative Technology to Gold Refining}

Mintek developed the Minataur leach/solvent extn./precipitation technology as a cost-effective, easily operated alternative to conventional gold refining processes. S. Scott, K. Matchett from Mintek, Randburg, South Africa, Journal of the South African Institute of Mining \& Metallurgy 2004, 104(6), 339. The technolology was first commercialized at the Harmony Gold Refinery in 1997 to produce $99.99 \%$ gold product and has subsequently led to development of various value-addition steps including the casting of various investment bars, gold wire drawing and gold potassium cyanide powder production In addition to refining gold to high purity, if an appreciable amt. of silver is present in the feed it is also refined to $99.99 \%$ purity. The major advantage that the Minataur technol. has over other gold refining processes is the relatively low gold lock-up and reduced operating costs. The operating cost, as at Apr. 2001 for the expanded Harmony refinery 24-ton/yr gold prodn. was approx. half that of conventional smelting and toll refining. The extractant employed for solvent extn. is relatively cheap and highly selective for gold to make the technol. attractive in situations where significant quantities of platinum group metals or base metals are present.

\section{General}

\subsection{Research on the Traditional Metal Decoration using Gold Foil (I Report)}

Decorative items comprising Ag substrate and Gold foil layer had been made in old times. However, this technique is not used in jewelry industries now. K. Morimoto, F. Suzuki, K. Kobayasi from Yamanashi Prefectural Industrial Technology Center, Japan Yamanashi-ken Kogyo Gijutsu Senta Kenkyu Hokoku 2003, 17, 118. Experiments have been carried out in this study to investigate the effects of foil thickness, temperature, Ag substrate on the quality of pressure bonding. Several samples were fabricated using the technique.

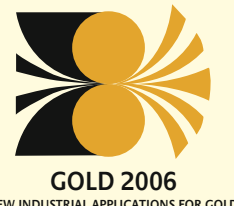

NEW INDUSTRIAL APPLICATIONS FOR GOLD

\title{
GOLD 2006 NEW INDUSTRIAL APPLICATIONS OF GOLD
}

\begin{abstract}
The 4th International Conference on Gold Science, Technology and its Applications will take place on
\end{abstract} 3rd-6th September, 2006, at the University of Limerick, Limerick, Ireland.

See website for full information.

Call for papers: Abstracts are invited for papers and posters by 16th January 2006.

Full details on conference website at: www.gold2006.org 